\title{
DETERMINANTS OF CONSUMER PURCHASE INTENTION OF HALAL MEAT IN KANO-NIGERIA: A CONCEPTUAL PAPER
}

\author{
Sulaiman Bin Yahya ${ }^{1^{*}}$ and Shaizatulaqma Kamalul Ariffin ${ }^{1}$ \\ ${ }^{1}$ Graduate School of Bussiness, Universiti Sains Malaysia
}

\begin{abstract}
The trend in the consumption of halal food products is experiencing daily increase, as a result of the fact that the demand of halal food products is becoming higher and higher from consumers world-wide due to its safety, hygiene and quality. Even though the issue of the demand of halal food products has been widely highlighted in some existing halal literature, the determining factors influencing consumer purchase intention of halal meat product in Kano-Nigeria is yet to be discussed well in the current literature. This concept paper will discuss factors such as attitude, subjective norm, perceived behavioural control, product knowledge, product trust, celebrity endorsement, religiosity, and personal norm as an extension of theory of planned behaviour (TPB) in the current complex food trade scenario. Cross-sectional quantitative survey approach will be used as the method of this study, using self-administered questionnaire to collect the data. 500 questionnaires will be distributed within the total population frame of 9 million people living in Kano. The research findings can provide valuable insights for halal meat retailers on influencing factors that affect consumer's intention to consume and purchase from them. The findings of this study will enrich existing literature on halal meat product as well as broaden and deepen the theory of planned behaviour. It may also contribute towards necessary policy changes surrounding the halal meat market in Kano-Nigeria. Empirical studies by future researchers can be employed to test the relationship between the factors and also uncover other factors that can help in enhancing the purchase intention of halal meat product.
\end{abstract}

\author{
ARTICLE HISTORY \\ Received:11-4-2020 \\ Accepted:3-6-2020
}

\section{KEYWORDS}

Consumer

Purchase

Halal meat

Religiosity and Kano

\section{INTRODUCTION}

The halal industry has been experiencing rapid growth globally in recent years, which its market is projected to appreciate from 2016 to 2022 by 28\% (Muneeza \& Mustapha, 2020). The strategies of market segmentation and positioning of the halal industry have shifted to the non-Muslim target market, which created an avenue for the industry to serve both Muslim and non-Muslim consumers (Abdullahi et al, 2020). This caused the development of the halal industry to become common in non-Muslim countries. As an example, the HFCE (Halal Food Council of Europe) has certified over 400 European food companies (Muneeza \& Mustapha, 2020). According to Visser (2019), the demand for halal products is rising in consumables products, such as food and beverages, cosmetics, and pharmaceuticals in concomitant with the traditional Islamic law that is expected to drive the entire global industry growth (see Figure 1). According to figure 1, findings revealed that by the year 2030, the Muslim population is expected to grow by 2.2 billion up from 1.7 billion in 2014. It also revealed that presently, the Muslim population accounts for $20 \%$ of the global population.

Another study indicated that, in 2017, 7.5\% of Malaysia's GDP is contributed by the halal industry (Abdullahi et al, 2020). This is very interesting to be observed by developing countries and marketing organizations due to the fact that the halal industry is now regarded as the engine of economic growth in the world. Pew Research Centre (2019) reported that the population of Muslims worldwide is expected to increase by 75\% from 1.6 billion in 2010 to 2.8 billion in 2050 (Yagmur, Ehtiyar, \& Aksu, 2019). It also reported that the spending on halal products projected compound annual growth rate (CAGR) will experience a growth of 6.2\% from 2018-2024. The Global Islamic Report (GIR, 2019/2020) reported that halal food items will experience an increase from \$1.37 trillion in 2018 to $\$ 1.97$ trillion in 2024 with a CAGR of 6.3\% (Ho, Abd Rahman, Yusuf, \& Zamzamin, 2014). This is due to the fact that the demand for a halal food product is becoming higher and higher among consumers worldwide due to its safety, hygiene, and quality as indicated in the Holy Qur'an. Moreover, the Prophet Muhammad (SAW) indicated the command of Allah (SWT) on how Muslims are instructed on the issue of haram and haram food products in Sahih Al-Bukhari, Vol. 1. Hadith No 49.

Nigeria has the largest Muslim population in African countries and the $8^{\text {th }}$ largest in the world, according to the HDC 2019 report (Godbold, 2010), following the suite of demanding halal meat products. According to Astou (2015), there has been an encouragement by the Ministry of Agriculture for Nigeria to look forward to boosting its capacity in the area of halal product production in order to meet the halal needs. Research indicated that 77.3 million people representing $50 \%$ 
of over 200 million Nigerian population are Muslims (Annabi \& Ahmed, 2015). It is the largest among the African countries with $2.64 \%$ of the total world population, according to the United Nations world population in the year 2020 (Gerland et al., 2014). While writing on halal beef in Nigeria, Jakada and Gambo (2014) observed that the concept of halal has applications beyond religious choices, attracting other consumers who were motivated by environmental and health considerations. This indicated that the potential of halal meat is beyond the Muslim population in Nigeria. Kano State is one of the major industrial states in Nigeria located in North-Western Nigeria. It was created on May 27, 1967, from part of the Northern Region, Kano state borders Katsina State to the north-west, Jigawa State to the north-east, Bauchi and Kaduna states to the south, with the name 'Kano' as the state capital (Mohammed, Musa, \& Jeb, 2014). Research findings indicated that Kano state has been considering to be the second biggest industrial center in Nigeria and the largest in Northern Nigeria with the provision of products in the area of cosmetics, textile materials, tannery production, footwear, plastics, pharmaceuticals, ceramics works, furniture, and other industries. Other areas of capacity building include agricultural implements, food, and beverages, provision of dairy products, animal feeds, vegetable oil, etc. (Mohammed et al., 2014).

Global halal market revenue, 2014 - 2024 (USD Trillion)

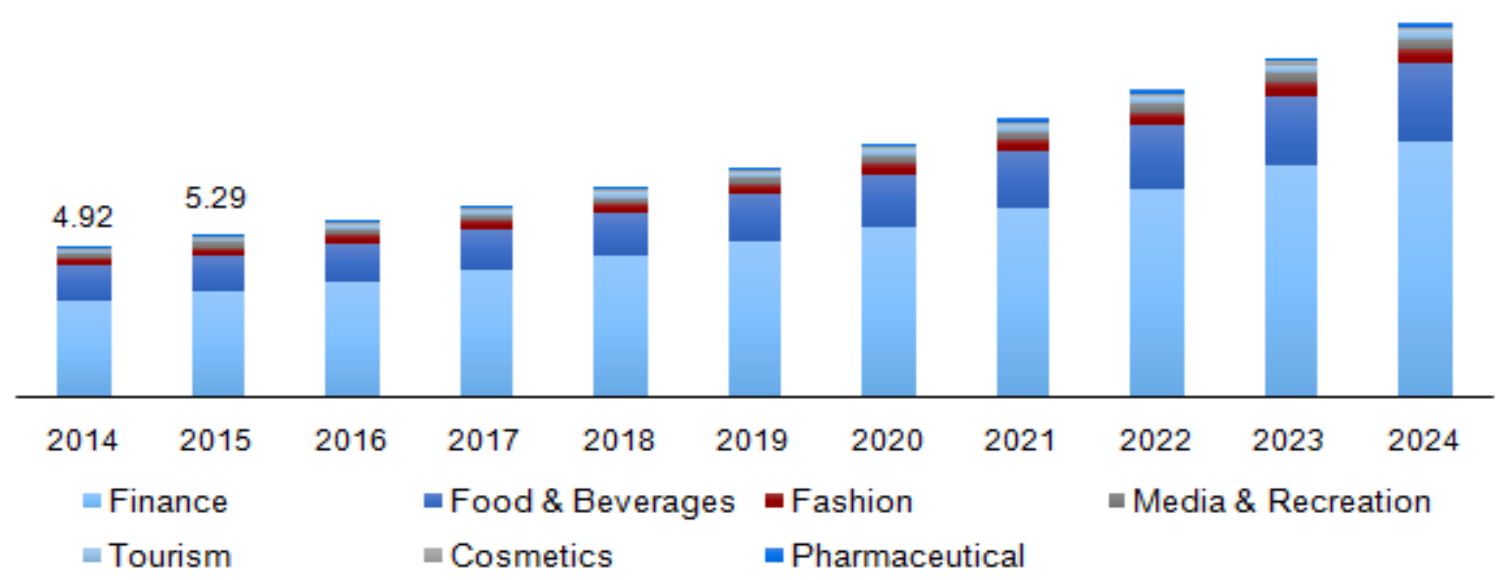

Figure 1. Global halal market revenue, 2014 - 2024 (USD Trillion)

According to Figure 1, the halal food industry has a significant share in the global economy. Research findings revealed that the number of empirical studies that have been conducted on the consumer purchase behaviour of halal food in Nigeria is considered inadequate (Khan \& Khan 2016). Annabi and Ahmed (2015); Annabi and Ibidapo-Obe (2017); Jaiyeoba, Abdullah, and Dzuljastri (2019) reported that halal certification, halal processing, halal value chain, and Islamic advertising are all lacking in Nigeria. This indicated that more studies need to be conducted in the area of halal food production to boost the economy of Nigeria.

The present study is to be conducted in Kano with a population of over 9 million people of which $90 \%$ of the population are Muslims (Ezeah, Iyanda, \& Nwangw, 2013). Only studies by Adetunji, Oladejo, and Ojedokun (2016) and Abdullahi et al. (2020) attempted to explore determinants of consumer purchase intention of halal meat in Nigeria. These studies were testing variables like attitude, subjective norm, perceived behavioural control, habit, perceived health risk, and perceived norm. These previous studies turndown to cover factors like religiosity (Ismail, Abdullah, Ahmad, \& Sidek, 2018), Islamic Advertisement (Souiden \& Rani, 2015; Ali, Xiaoling, Sherwani, \& Ali, 2017), personal norm (Erdogan, 1999), and celebrity endorsement which all showed significant results.

Jakada and Gambo (2014) reported that Kano state with over 9 million Muslims which is $90 \%$ of the Muslim population in Nigeria has the potential of a halal meat market than South Africa, Germany, UK, Italy, Brazil, and Canada. This problem prompted the state government to enter into a partnership with Bovine Master, an Egyptian company, to build a halal meat factory in Kano state. It is expected that the first phase of the project would gulp an estimated \$12 million. The factory would entail cattle and small ruminant's meats processing, sales, and logistics to create more value and GDP growth for Kano (Punch 29th Sep. 2018). According to the present Kano state governor, Dr. Abdullahi Umar Ganduje, he stated that the project will provide a fully certified halal meat brand for domestic as well as key halal export markets in North Africa and the GCC countries. "In addition, the project in collaboration with relevant agencies aims to establish a halal food certifying body in the state", he stressed. The governor explained that the project would create more value and GDP growth for Kano by distributing and exporting finished products as opposed to the prevailing livestock to end-user markets approach in the country (Daily Halal Market New, 2020).

This effort by the Kano state government motivated the interest of the study to find out what factors will trigger consumer purchase intention of halal meat products in Kano. This is to add value to various efforts made by other 
researchers in determining factors influencing consumer purchase intention of halal meat products in Kano using an extended theory of planned behaviour (ETPB). Therefore, the model used in this paper was based on ETPB as shown in Figure 2. Similarly, there are numerous studies such as by Grunert and Wills (2007) explaining household food purchase behaviour. However, the majority of these studies focused on the developed countries, perhaps due to the demand being more in those countries.

This paper intends to discuss factors such as attitude, subjective norm, perceived behavioural, trust, knowledge, celebrity endorsement, religiosity, and personal norm as an extension of the theory of planned behaviour in the current complex food trade scenario.

However, to the best of our knowledge, no prior studies investigated the major determinants of consumer purchase intention of halal meat in Kano, Nigeria by applying the ETPB. Against this backdrop, the paper intends to apply and extend the (ETPB) in determining the factors that influence consumer purchase intention of halal meat products from a survey in Kano State, Nigeria. The specific objectives of the paper are to:

1. Apply and extend the (ETPB) in determining consumer purchase intention of halal meat product in Kano;

2. Identify the factors that affect consumer purchase intention in Kano; and

3. Provide theoretical support to the use of ETPB in determining consumers purchase intention of halal meat in Kano

\section{LITERATURE REVIEW}

The issue of halal (permissible) food consumption, and meat that is ritually slaughtered in particular, is extremely vital for any Muslim society, as the decree to eat meat which is halal (and indeed tayyib, or wholesome) is a fundamental aspect of the Islamic way of life as decreed within the Qur'an and Hadith of the Holy Prophet (SAW). Since no signage available, it can be very difficult for a Muslim consumer to know the provenance of the meat that they buy and the basis by which it is deemed to be halal in some non-Muslim countries. At the same time, there is arguably little action to stop any butcher, restaurant, or takeaway claiming that their meat is halal, without fear of legally enforceable consequences if this turns out to be a dubious or baseless assertion. The dynamics of the halal market have also led to the alleged sale of non-halal meat by unscrupulous halal butchers (Alhabshi, 2013).

Allah (SWT) has commanded all mankind to eat meat which is halal in the holy Qur'an. He says: "O ye people! Eat of what is on earth, lawful and good (pure, clean); and do not follow the footsteps of the Evil One...” (Ali, 1991: 2/168); and "O ye people! Eat of the good (pure, clean) things that we have provided for you..." (Ali, 1991: 2/172). This verse indicated that it is a divine command from Allah (SWT) that people must adhere to by eating food products that are considered to be halal in nature. Subsequently, Varinli, Erdem, and Avcilar (2016) reported that halal food as a global term, maybe the same as other foods visually but the quality, contents, type of process, different methods used in the operating process from the beginning to the end have all been approved and recommended by Islamic rules through various verses in the Holy Qur'an. From the findings of Abdul et al. (2020), halal food means foods complying with the rules set by Islamic jurisprudence in all stages of production and consumption. To sum it all, halal food consumption has become an area of discussion as a vital issue in Islamic marketing literature.

According to the Hadith of the Prophet (SAW) which was narrated by one of his companion, An-Numan Bin Bashir (RA) said that he heard the Messenger (SAW) saying "Both legal and illegal things are evident but in between them there are doubtful (unclear) things, and most of the people have no knowledge about them. He further reported that the Prophet (SAW) continues to say" whoever saves himself from these unclear things, he saves his religion and his honour and whoever indulges in these unclear things is like a shepherd who grazes (his animals) near the Hima (private pasture) of someone else, and at any moment he is liable to get in it". He also narrated that, the prophet (SAW) said "(O people) Beware! Every king has a Hima and the Hima of Allah (SWT) on the earth is His illegal (forbidden) things". Numan finally reported that the prophet (SAW) concluded by saying, "Beware! There is a piece of flash in the body if it becomes good (reformed), the whole body becomes good, but if it gets spoilt, the whole body gets spoilt and that is the heart." (Sahih Al-Bukhari, Vol. 1. Hadith No 49).

The above Hadith of the prophet is a clear indication that a Muslim intends to do most be in accordance with the teaching of Islam because things that are halal (Lawful) and haram (Forbidden) are issues that have been clarified by Allaah (SWT) in all the revealed scriptures. However, in Islam, the idea of food consumption is not meant for the sake of enjoyment, but rather to sustain one's life so that mankind can perform ibadah (prayer) to Allah (SWT) in a situation that considered to be healthy, and their physical strength to be able to undertake their duties and responsibilities in this life. Above all, Islam stated that in order to get the right physical and spiritual strength, one should consume only halal thayyiban food (lawful wholesome food) as mentioned earlier in Surah Al-Maidah (V5:88).

\section{An extended theory of planned behaviour (ETPB)}

Behavioural intention is considered to be a situation whereby a person has the skills, resources, and other prerequisites needed to perform a certain behaviour (Bray, 2008). Several studies by Ahmed, Najmi, Faizan, and Ahmed (2019); Souiden and Rani (2015); and Abdullahi (2017) proved the Theory of Planned Behaviour (TPB) as a strong theory in determining consumer purchase intention of the halal product. That is why the study selected the theory to contribute academically by extending it with variables such as celebrity endorsement, religiosity, and personal norm. 


\section{Attitudes towards purchase intention relationship}

Presley, Damron-Martinez, and Zhang, (2010) defined an attitude as the likelihood that a person will respond favourably or unfavourably to an object or behaviour, based on a predisposition. This indicated that comprehending a consumer's attitude toward intention to purchase halal meat is often the first step in understanding consumer behaviour, as attitude has been found to directly influence behaviour (Ajzen, 2011). The attitude became a significant variable for researchers in the social and behavioural sciences to measure the behavioural intention of consumers (Han, Hsu, \& Sheu, 2010). Studies by Palmer (2010) proved the validity of attitude as a significant variable in measuring consumer intention to purchase halal products in many countries. To sum it up, attitude represents a summary of the evaluation of a psychological object captured in such attribute dimensions as pleasant-unpleasant, good-bad, harmful-beneficial, and likable-dislikeable (Ajzen, 2011). The first hypothesis developed in this study is:

$\mathrm{H}_{1}$ : There is a positive and significant relationship between attitude towards halal meat products and purchase intention of halal meat products.

\section{Product Knowledge}

Product knowledge is defined as the awareness of the consumer to look for information about a product (Lin \& Chen, 2006). The main source of product knowledge includes the consumer's experience towards the product and the advertisement media which was stated to influence the consumer's decision to buy or to choose the product. Lu, Chang, and Chang (2014) proved product knowledge as a significant variable in strengthening consumer attitude toward purchase intention.

These days, Muslim consumers are faced with a broad selection of Halal products and services. Each product group offers many different local and internationally recognized brands. These brands (hereinafter referred to as Halal brand) use Halal logos or/and symbols that provide assurance to the consumers particularly the Muslims that the ingredients used and the production processes are according to Islamic Shariah (Feick \& Price, 1987).

Due to rising competition, it is increasingly difficult for businesses to create a differential advantage in order to attract new customers. Therefore, one of the approaches to achieve brand differentiation, a perception of improved quality and overall customers support without major product modification may involve getting a certification or endorsement by a third party, for instance, an independent agency or association which is well respected by consumers (Ali, Xiaoling, Sherwani, \& Ali, 2018). That is to say, in order to differentiate a Halal brand from the traditional brand, companies get Halal certifications and then use the specific label to tell potential customers that their brand encompasses Halal features. Halal is a product characteristic refers to the nature, origin, and the processing method of the food, which implicates similarities with, for instance, foods produced considering sustainability issues or organic foods (Bonne \& Verbeke, 2008) as well as kosher foods. Consumers cannot see and validate these characteristics even after experiencing the product, thus yielding possible quality uncertainty during the pre-purchasing stage (Bonne \& Verbeke, 2008). The Halal label just like the green label, kosher label, and organic label can provide confidence to consumers on the Halal aspect of products and services which they use. The second hypothesis developed based on this matter is:

$\mathrm{H}_{2}$ : There is a positive and significant relationship between product knowledge and attitude towards purchase intention of Halal meat products.

\section{Product trust}

Trust has been described as a readiness to depend or to become vulnerable to the other party when one cannot control the other party's actions (McKnight \& Chervany, 2001a). The concept of trust is considered to be one of the fundamental bases of trade (McKnight \& Chervany, 2001b). It reported that, in the trend of commerce activities, trust issues have always been fundamentally debated because it affects business strategies and processes, branding, organizational structure and sizes, and the inclusion of multiple supporting operational practices that usually go with the daily business operations within an organization (Usman \& Kumar, 2020). The religious upbringing of a person can play a vital role in trust formation. The certainty of the genuine Halal food product is the most important to the practicing Muslim consumers in the case of Halal food consumption. Muslim consumers' trust is a crucial matter as religion influences such decisions. This is because consumers sometimes cannot verify even after its consumption whether the food was Halal or Haram. Sherwani, Ali, Ali, Hussain, and Zadran, (2018) hold the view that halal food holds typical credence process characteristic which is very important to Muslim consumers, citing an instance that, a quality characteristic that can hardly be evaluated or ascertained by the individual consumer, even upon or after consuming the food. To this end, product trust is a vital variable to be considered in the issue of halal product consumption. Hence, the third hypothesis is developed as follows:

$H_{3}:$ There is a positive and significant relationship between product trusts and attitude towards purchase intention of Halal meat product.

\section{Subjective norm}

Subjective norm as one of the variables in consumption intention was viewed by Ajzen (2011) as an individual's perceived social pressure from other people or groups who are important to him/her that wish or expect him/her to perform in a certain way. Furthermore, he stated that subjective norm makes a social burden about to perform or not to perform a 
specific behaviour (Astou, 2015; Godbold, 2010). Studies indicated that two items were normally used to measure subjective norms (e.g., "People who are important to me" (e.g., family and friends) expecting that my household is not consuming beef as it should be, as reported by (Mohammed et al., 2014), and was with the belief that underlies the subjective norm is known as 'normative beliefs'. They further stated that if the person that they believe is essential referents, they think that the behaviour should be performed. Moreover, Muneeza and Mustapha (2020) indicated that subjective norm interestingly is the most reliable predictor for choosing Halal products compared to other components in TPB. This scholarly view, however, posited that subject norm can be used to determine consumer purchase intention. Therefore, the hypothesis is proposed:

\section{$H_{4}$ : There is a positive and significant relationship between subjective norms and purchase intention of Halal meat product.}

\section{Perceived behavioural control}

Masese (2002) regarded perceived behavioural control to be the ability of a person's anticipation that execution of behaviour is within his/her control jurisdiction. Perceived behavioural control is also termed as the product of control beliefs and has interior control factors such as feelings and exterior control factors such as chances and dangers in the marketplace. As viewed by Jackson (2010), when consumers can control a specific behaviour that has ease of access, then the consumers perceive high control. However, a person's resources such as time availability, budget projection, and skill can increase consumer behavioural intentions when it comes to the issue of purchase decisions specifically in the area of Halal food consumption (Rezai, 2008). This indicated that perceived behavioural control is within the individual ability to control behaviour.

\section{$\mathrm{H}_{5}$ : There is a positive and significant relationship between perceived behavioral control towards halal meat product and purchase intention of Halal meat product}

\section{Celebrity endorsement}

Celebrity endorsement is one of the variables to be used in determining the consumer purchase intention of Halal meat in this study. In order to provide a clear picture of what celebrity endorsement entails, Awan, Siddiquei, and Haider (2015) stated that an endorser of any kind of product is a figure acting as a supporter in commercials advertisements used by many organizations to promote their products. Endorsers can function in two ways: celebrity endorser and endorser from common people. The study indicated that basically, the two types have the same attributes and characteristics as they are distinguished only by the same factor as reported by Nasir, Khan, Sabri, and Nasir (2016). Many consumers are attracted by the action of celebrity endorsers to gain attention during the introduction of new products. Celebrity attracts attention and helps to introduce products to customers and a celebrity favoured by the general public is capable to attract a higher recall. The main task of this is to create a good association between himself/herself and a product advertised until the expected positive attitude among customers is achieved. 'Advertising is an important element in instilling brand image to customers, along with physical characteristics and quality of a particular brand (Nurhayati \& Hendar, 2019). Suki (2014) stated that celebrity endorser credibility has 3 dimensions affecting the message and the power of persuasion, namely (1) attractiveness, which is the degree with which an object is assessed through a sympathetic attitude, has ambitions, intelligence, and other personality characteristics (attractive, classy, beautiful, sexy, elegant, etc.); (2) trustworthiness, which is the rate at which an object is considered as an honest information provider and also as reliable, sincere, etc.; (3) expertise, the degree to which an object is assessed through sympathetic behaviour, has the ambition, intelligence and other personality characteristics (experience, knowledge, qualification, skills). Madiawati and Pradana (2016) viewed that celebrities can be a vital tool in creating attention, interest, or actions with regards to determining a decision on purchasing or using a specific product. Studies showed that celebrities represent an idealization of life that most people imagine that they would love to live which is usually viewed by their followers and in some cases, the general public, (Madiawati \& Pradana, 2016). This indicated that celebrities could be a powerful variable to determine the buying intention of consumers with regards to the purchase of Halal meat.

\section{$H_{6}:$ There is a positive and significant relationship between celebrity endorsement towards halal meat product and purchase intention of Halal meat product.}

\section{Religiosity}

An individual decision usually goes by value and belief. Mokhlis (2006) considered religion as the degree to which certain values and beliefs to certain ideals are held and practiced, and become a mark of identity of individual who practices such religion. Religiosity is also viewed as how far individual pledges towards her religion and acknowledges its religious teaching, such as the behaviour and attitude which mirror her commitments (Mokhlis, 2010). Religiosity refers to a person's beliefs about the absolute inherent truth qualities and definitiveness of a religion's scriptures and teachings (Mokhlis, 2010). It has also been indicated that the level of religiosity becomes the key factor to indicate the Muslim consumer's attitude towards consumer purchase intention. Religiosity includes five dimensions, which are rituals, ideology, intellectual, experience, and consequence.

Studies showed that religion can be viewed internally and externally. Viewing religion from the internal perspective, a person can have a religious identity for his/her values, development, attitudes, habit, and religious beliefs. Externally, 
religion can be viewed from religious affiliation, worship services, and membership in religious communities, or attending religious functions. Ismail et al., (2018) suggested that one of the powerful variables that are significant in influencing the cognitive and behaviour of consumers is their religious inclination and affiliation. This is because religion can serve as a variable in determining their purchase decision of goods and services. This study considered the use of religion as a variable in determining consumer purchase intention.

$H_{7}:$ There is a positive and significant relationship between religiosity towards halal meat product and purchase intention of Halal meat product.

\section{Personal norm}

Personal norms are viewed as expectations that individuals hold for themselves, which are derived from social norms, and are vital factors in determining human behaviour yet they are heterogeneous across individuals (Kuran, 1998). Personal norms are learned in and modified through social interaction which is tied to a person's self-image and are enforced through mechanisms such as guilt or pride as indicated by Grunert and Wills (2007). A study by Grunert and Wills (2007) viewed norms to be homogenous across individuals within a population. This study showed that personal norms may be heterogeneous across the population and different individuals may ascribe different thresholds for intention to purchase products. While writing on consumers' intention to purchase beef, Abdullahi et al. (2020) reported that personal norm was measured using the statement, "No matter what will happen or what people say or think due to my principles, I feel it is compulsory for me to purchase beef for the household" (Palmer, 2010). It is expected that participants would show a higher tendency of a personal norm or pro-social behaviour. However, Presley et al. (2010) argued that the same response would not be obtained if we target a negative personal norm. Studies that were conducted in Pakistan and Malaysia using personal willingness to pay for halal products, indicated personal norm as a positive variable in determining consumer purchase intention.

\section{$H_{8}$ : There is a positive and significant relationship between personal norm towards halal meat product and purchase} intention of Halal meat product

This paper, therefore, intends to apply and extend the (TPB) in determining consumer purchase intention of halal meat product, identify the factors that affect consumer purchase intention, and provide theoretical support to the use of ETPB in determining consumers purchase intention of halal meat in Kano. The conceptual framework is shown in Figure2.

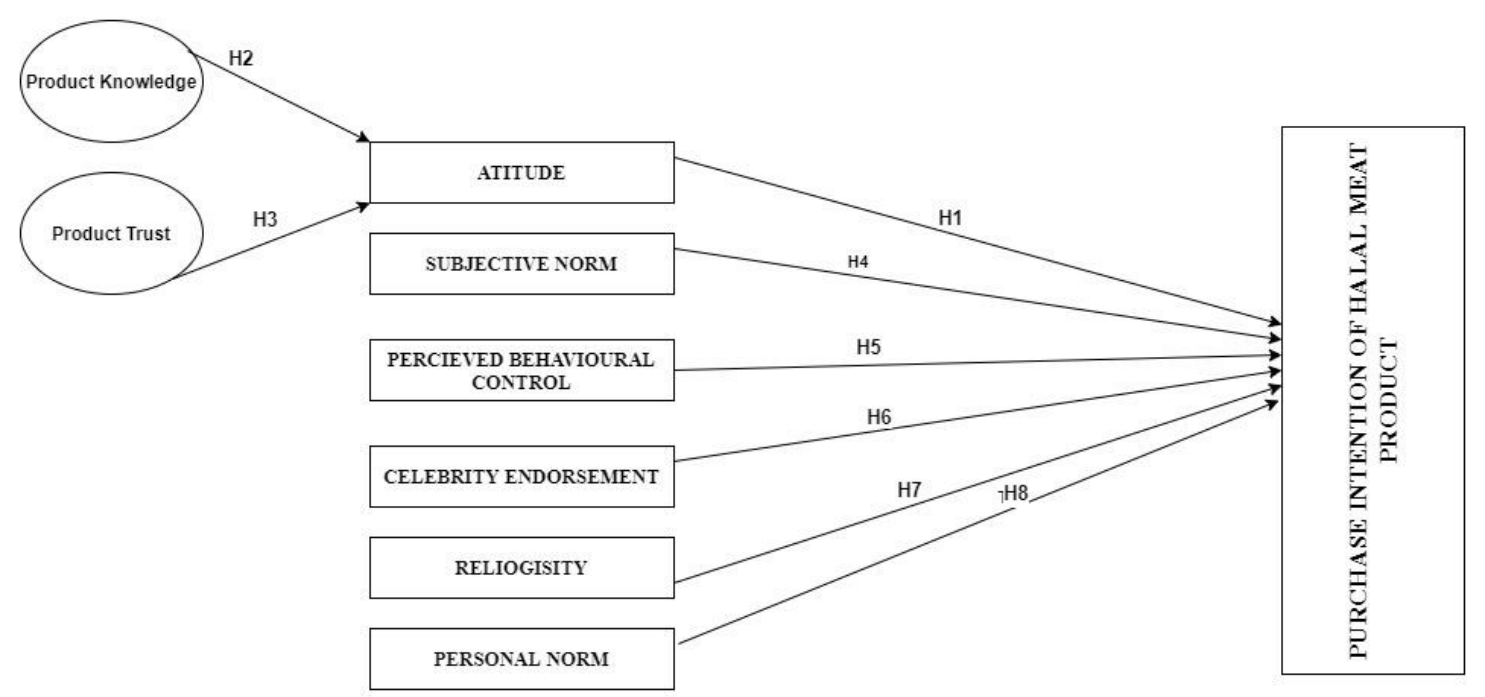

Figure 2. Conceptual Framework

A cross-sectional quantitative survey approach will be used as the method in this study, using a self-administered questionnaire to collect the data. 500 questionnaires will be distributed within the total population frame of 9 million people living in Kano. 


\section{THEORETICAL AND PRACTICAL IMPLICATIONS}

The research findings can provide valuable insights for halal meat retailers on influencing factors that affect consumer's intention to consume and purchase from them. The findings of this study will enrich existing literature on halal meat products as well as broaden and deepen the theory of planned behaviour. It may also contribute towards necessary policy changes surrounding the halal meat market in Kano-Nigeria.

\section{CONCLUSION}

Considering the importance of the growing Halal food industry in the world, the understanding of Muslim consumer intention to purchase halal meat products becomes imperative. It is essential for marketers to understand the factors that determine Muslim consumers' intention to purchase halal meat in Kano, Nigeria. This will inevitably allow a proper marketing strategy towards the target market. Hence, a conceptual model has been drawn with regards to possible factors that may likely influence Muslim consumers' purchase intention of halal meat products. These factors include attitude, subject norm, perceived behavioral control, celebrity endorsement, religiosity, and personal norm, considered as determinants towards Muslim consumer purchase intention of halal meat product in Kano, Nigeria. The ultimate aim of this paper is to provide a model that could enhance the performance of the Nigerian Halal food industry.

\section{REFERENCES}

Abdullahi, N. M., Huo, X., Shahriar, S., Kea, S., Abdullahi, A. M., \& Abubakar, M. I. (2020) Determinants of household beef purchase intention: An application of the extended theory of planned behavior.

Abdullahi, S. I. (2017). Islamic advertising in Nigeria: an assessment. International Journal of Islamic Marketing and Branding, 2(1), 65-84.

Adetunji, M., Oladejo, J., \& Ojedokun, I. (2016) ASSESSMENT OF HOUSEHOLD DEMAND ON LOCUST BEANS (PARKIA BIGLOBOSA) IN SOUTH WEST, NIGERIA. ARCA, 173.

Ahmed, W., Najmi, A., Faizan, H. M., \& Ahmed, S. (2019). Consumer behaviour towards willingness to pay for halal products. British Food Journal.

Ajzen, I. (2011). Job satisfaction, effort, and performance: A reasoned action perspective. Contemporary Economics, $5(4), 32-43$.

Alhabshi, S. M. (2013). Halal Food Dilemmas: Case Of Muslims In British Columbia, Canada. International Journal of Asians Social Sciences, 850.

Ali, A., Xiaoling, G., Sherwani, M., \& Ali, A. (2017). Factors affecting Halal meat purchase intention. British Food Journal.

Ali, A., Xiaoling, G., Sherwani, M., \& Ali, A. (2018). Antecedents of consumers' Halal brand purchase intention: an integrated approach. Management Decision.

Annabi, C. A., \& Ahmed, J. L. (2015). Halal Beef Handling in Nigeria: The Abattoir Workers ${ }^{\text {ee }}$ Perspective. Journal of Emerging Economies and Islamic Research, 3(2), 62-78.

Annabi, C. A., \& Ibidapo-Obe, O. O. (2017). Halal certification organizations in the United Kingdom. Journal of Islamic Marketing.

Astou, D. (2015). Food Imports as a Hindrance to Food Security and Sustainable development: The Cases of Nigeria and Senegal.

Awan, H. M., Siddiquei, A. N., \& Haider, Z. (2015). Factors affecting Halal purchase intention-evidence from Pakistan's Halal food sector. Management Research Review.

Bonne, K., \& Verbeke, W. (2008). Muslim consumer trust in halal meat status and control in Belgium. Meat science, 79(1), 113-123.

Bray, J. P. (2008). Consumer behaviour theory: approaches and models.

Erdogan, B. Z. (1999). Celebrity endorsement: A literature review. Journal of marketing management, 15(4), $291-314$.

EZEAH, P., Iyanda, C. C., \& Nwangw, C. (2013). Challenges of national population census and sustainable development in Nigeria: A theoretical exposition. IOSR Journal Of Humanities And Social Science (IOSR-JHSS), 18(1), 5056.

Feick, L. F., \& Price, L. L. (1987). The market maven: A diffuser of marketplace information. Journal of marketing, 51(1), 83-97.

Gerland, P., Raftery, A. E., Ševčíková, H., Li, N., Gu, D., Spoorenberg, T., . . . Lalic, N. (2014). World population stabilization unlikely this century. Science, 346(6206), 234-237.

Godbold, R. (2010). Informed consent and midwifery practice in New Zealand: lessons from the Health and Disability Commissioner. New Zealand College of Midwives Journal(42).

Grunert, K. G., \& Wills, J. M. (2007). A review of European research on consumer response to nutrition information on food labels. Journal of Public Health, 15(5), 385-399.

Han, H., Hsu, L.-T. J., \& Sheu, C. (2010). Application of the theory of planned behavior to green hotel choice: Testing the effect of environmental friendly activities. Tourism management, 31(3), 325-334.

Ho, C. S. F., Abd Rahman, N. A., Yusuf, N. H. M., \& Zamzamin, Z. (2014). Performance of global Islamic versus conventional share indices: International evidence. Pacific-Basin Finance Journal, 28, 110-121. 
Ismail, I., Abdullah, N. A. N., Ahmad, Z., \& Sidek, N. L. (2018). Halal principles and halal purchase intention among Muslim consumers. Paper presented at the Proceedings of the 3rd International Halal Conference (INHAC 2016).

Jackson, M. (2010). pAn Overview of Social Networks and Economic Applicationsq, in eds. J. Benhabib, A. Bisin, and MO Jackson, The Handbook of Social Economics: Elsevier Press.

Jaiyeoba, H. B., Abdullah, M. A., \& Dzuljastri, A. R. (2019). Halal certification mark, brand quality, and awareness. Journal of Islamic Marketing.

Jakada, B. A., \& Gambo KK, M. (2014). A Conceptual Analysis of Market Orientation Philosophy in the Hospitality Industry of Nigeria. Journal of Marketing \& Management, 5(1).

Khan, G., \& Khan, F.(2016) The role of packaging in determining the 'Halalness' of products: An exploratory study of

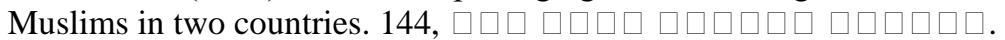

Kuran, T. (1998). Ethnic norms and their transformation through reputational cascades. The Journal of Legal Studies, 27(S2), 623-659.

Lin, L. Y., \& Chen, C. S. (2006). The influence of the country-of-origin image, product knowledge and product involvement on consumer purchase decisions: an empirical study of insurance and catering services in Taiwan. Journal of consumer Marketing.

Lu, L.-C., Chang, W.-P., \& Chang, H.-H. (2014). Consumer attitudes toward blogger's sponsored recommendations and purchase intention: The effect of sponsorship type, product type, and brand awareness. Computers in Human Behavior, 34, 258-266.

Madiawati, P. N., \& Pradana, M. (2016). Celebrity and halal certificates factors influence on customers' buying interest. Актуальні проблеми економіки(3), 109-116.

Masese, R. E. (2002). The influence of socio-cultural factors on Health Seeking behaviour: A study of Malaria control in Sameta Division, Kisii District.

McKnight, D. H., \& Chervany, N. L. (2001a). Trust and distrust definitions: One bite at a time Trust in Cyber-societies (pp. 27-54): Springer.

McKnight, D. H., \& Chervany, N. L. (2001b). What trust means in e-commerce customer relationships: An interdisciplinary conceptual typology. International journal of electronic commerce, 6(2), 35-59.

Mohammed, M., Musa, I., \& Jeb, D. (2014). GIS-based analysis of the location of filling stations in metropolitan Kano against the physical planning standards. American Journal of Engineering Research, 3(9), 147-158.

Mokhlis, S. (2006). The influence of religion on retail patronage behaviour in Malaysia.

Mokhlis, S. (2010). Religious contrasts in consumer shopping styles: a factor analytic comparison. Journal of Business Studies Quarterly, 2(1), 52.

Muneeza, A., \& Mustapha, Z. (2020). Halal certification process for fisheries products in Maldives. Journal of Islamic Marketing.

Nasir, N., Khan, S., Sabri, P. S. U., \& Nasir, S. (2016). CELEBRITY ENDORSEMENT AND CONSUMER BUYING INTENTION WITH THE MEDIATING ROLE OF BRAND PERFORMANCE: AN EMPIRICAL CONSUMER PERCEPTION STUDY IN FMCG SECTOR OF PAKISTAN. Science International, 28(1).

Nurhayati, T., \& Hendar, H. (2019). Personal intrinsic religiosity and product knowledge on halal product purchase intention. Journal of Islamic Marketing.

Palmer, A. (2010). Customer experience management: a critical review of an emerging idea. Journal of Services marketing.

Presley, A., Damron-Martinez, D., \& Zhang, L. (2010). A study of business student choice to study abroad: A test of the theory of planned behavior. Journal of Teaching in International Business, 21(4), 227-247.

Rezai, G. (2008). Consumers' Confidence in Halal Labeled Manufactured Food in Malaysia. Universiti Putra Malaysia.

Sherwani, M., Ali, A., Ali, A., Hussain, S., \& Zadran, H. G. (2018). Determinants of muslim consumers' Halal meat consumption: applying and extending the theory of planned behavior. Journal of Food Products Marketing, 24(8), 960-981.

Souiden, N., \& Rani, M. (2015). Consumer attitudes and purchase intentions toward Islamic banks: the influence of religiosity. International Journal of Bank Marketing.

Suki, N. M. (2014). Does celebrity credibility influence Muslim and non-Muslim consumers' attitudes toward brands and purchase intention? Journal of Islamic Marketing.

Usman, M. U., \& Kumar, P. (2020). Factors Influencing Consumer Intention to Shop Online in Nigeria: A Conceptual Study. Vision, 0972262920926797.

Varinli, İ., Erdem, E., \& Avcilar, M. Y. (2016). Exploring the factors affecting purchase intention of halal certified foods in Turkey: a PLS-path modeling study. European Journal of Business and Management, 8(4), 68-78.

Visser, H. (2019). Islamic finance: Principles and practice: Edward Elgar Publishing.

Yagmur, Y., Ehtiyar, R., \& Aksu, A. (2019). Evaluation of halal tourism in terms of bibliometric characteristics. Journal of Islamic Marketing. 


\section{ACKNOWLEDGEMENT}

We write to acknowledged the esteem financial support granted by the Nigerian government through its agency Tertiary Education Trust Fund (TETfund), for funding this research work. Also, our profound appreciations goes to the management and staff of Graduate School of Business (GSB), Universiti Sains Malaysia (USM), for a well-organized 2nd International Conference for Business Sustainability and Innovation (ICBSI2020) that created an academic opportunity to undertake this research write up.

\section{AUTHORS BIOGRAPHY}

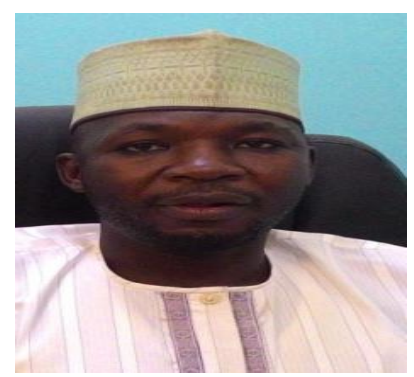

Sulaiman Bin Yahya is a staff of the Nigeria Police Academy, Wudil- Kano at the Faculty of Social and Management Sciences (SMS). He Holds Master of Business Administration specializing in Marketing in 2010 from Bayero University, Kano-Nigeria (BUK). He heads the exams and records unit of the university for 5 years after working in the state Polytechnic as Lecturer for over 12 years in service. He has attended several conferences within and outside Nigeria. He has published two marketing books with ISBN 978-2958-36-0 \& ISBN 978-2958-38-7 while in the service of the state Polytechnic. He is a member of National Institute of Marketing of Nigeria (NIMN) as a Chartered Marketer since 2005. Presently, he is undergoing his PhD programme in Marketing (Consumer Behavior) at Graduate School of Business (GSB), Universiti Sains Malaysia (USM).

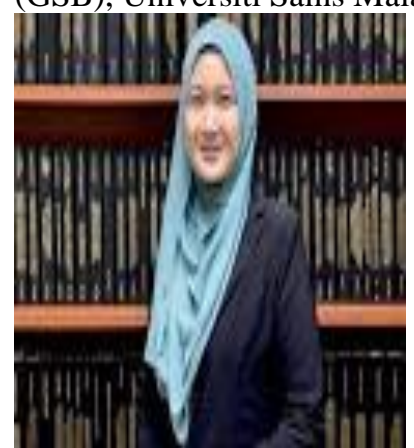

Dr. Shaizatulaqma Kamalul Ariffin is a Senior Lecturer in Marketing at the Graduate School of Business, Universiti Sains Malaysia (USM). She was conferred a PhD. in International Marketing from USM with a Master Science in Marketing from Texas A \& M university-Commerce, United States. She obtained her Bachelor's degree in Management from USM with a specialization in Marketing. She has presented numerous papers in conferences and has also published several research articles in Indexed Journals and proceedings. She is currently holding several grants to support her research on Marketing-related issues. She is also a member of the editorial board for several international journals. She is a fellow of USM Apex Young Scholar, and has received the Higher Commented Award 2019, Emerald Literati Winners by Emerald Publishing Limited, United Kingdom in 2019. 